\section{Distribution Volume of ${ }^{18}$ F-BMS-986192 in NSCLC Patients}

TO THE EDITOR: In an interesting article, Dr. Huisman et al. recently investigated the optimal kinetic model for an ${ }^{18} \mathrm{~F}$-labeled anti-programmed cell death ligand 1 (anti-PD-L1) adnectin, namely, ${ }^{18}$ F-BMS-986192, to quantify PD-L1 expression in non-smallcell lung cancer (NSCLC) patients (1). A single-tissue-reversible (STR) compartment model, additionally including blood-volume fraction, was found to be the most preferred model for fitting the tumor time-activity curves. Its specific outcome measure is the distribution volume $\left(V_{T} ; \mathrm{mL} . \mathrm{cm}^{-3}\right)$ that is the equilibrium ratio of forward/reverse transport-rate constants, that is, $\mathrm{K}_{\mathrm{i}} / \mathrm{k}_{\mathrm{b}}$, between blood and reversible-trapping compartment (2). $V_{T}$ was then used to validate simplified methods, the best correlation being obtained with body weight-normalized SUV $\left(\mathrm{SUV}_{\mathrm{BW}}\right)$ at 50-80 min after injection $\left(R^{2}=0.92-0.91\right)$, whereas a lower correlation was obtained with SUV normalized to plasma concentration (SUV/ $\mathrm{C}_{\text {plasma }}$, presumably at $50 \mathrm{~min}$ after injection; $R^{2}=0.84$ ). The authors conclude that $\mathrm{SUV}_{\mathrm{BW}}$ at $60 \mathrm{~min}$ after injection is an accurate simplified parameter for uptake assessment of ${ }^{18} \mathrm{~F}$ BMS-986192 baseline studies.

We would like to further analyze the latter lower correlation since, under postinjection time conditions we address in this letter: (i) $V_{T}$ may be assessed by the ratio of tissue/plasma tracer concentration, i.e., $\mathrm{C}_{\text {tissue }} / \mathrm{C}_{\text {plasma }}$; and (ii) the $\mathrm{SUV}_{\mathrm{BW}} / \mathrm{C}_{\text {plasma }}$ ratio may be also proportional to $V_{T}$ since $\mathrm{SUV}_{\mathrm{BW}}$ is proportional to $\mathrm{C}_{\text {tissue }}$. To clarify this issue, we have fitted the ${ }^{18} \mathrm{~F}-\mathrm{BMS}-986192$ input function with a triexponentially decaying function and then fitted a PD-L1-positive tumor time-activity curve by using a 3compartment 3-parameter kinetic model (data extracted from Figs. 3 and 4 in Huisman with the Web-Plot-Digitizer software; $R^{2}=0.996$ and 0.998 , respectively) $(1,3)$. Estimates of $\mathrm{K}_{\mathrm{i}}$ and $\mathrm{k}_{\mathrm{b}}$ were provided, leading to the computation of $V_{T}$ as $\mathrm{K}_{\mathrm{i}} / \mathrm{k}_{\mathrm{b}}=4.7$ $\mathrm{mL} . \mathrm{cm}^{-3}$. This analysis also allowed us to perform both decaycorrected tissue- and decay-uncorrected trapped-tracer time-activity curves (supplemental data, available at http://jnm.snmjournals.org).

Let us first consider the rate of decay-corrected trapped tracer per tissue volume unit (at steady state): $\mathrm{dC}_{\text {trapped }}(\mathrm{t}) / \mathrm{dt}=\mathrm{K}_{\mathrm{i}} \times \mathrm{C}_{\text {plasma }}(\mathrm{t})-$ $\mathrm{k}_{\mathrm{b}} \times \mathrm{C}_{\text {trapped }}(\mathrm{t})$. At peak time of decay-corrected $\mathrm{C}_{\text {trapped }}$ time-activity curve, $\mathrm{dC}_{\text {trapped }}(\mathrm{t}) / \mathrm{dt}=0$ and then $\mathrm{C}_{\text {trapped }}\left(\mathrm{t}_{\text {peak }}\right) / \mathrm{C}_{\text {plasma }}\left(\mathrm{t}_{\text {peak }}\right)=\mathrm{K}_{\mathrm{i}} / \mathrm{k}_{\mathrm{b}}=$ $V_{T}$. Assuming $\mathrm{C}_{\text {tissue }}\left(\mathrm{t}_{\text {peak }}\right) \approx \mathrm{C}_{\text {trapped }}\left(\mathrm{t}_{\text {peak }}\right.$ ) (i.e., neglecting free tracer in blood and interstitial volume), $\mathrm{t}_{\text {peak }}$ was estimated to be $87 \mathrm{~min}$ from decay-corrected $\mathrm{C}_{\text {tissue }}$ time-activity curve, leading to $\mathrm{C}_{\text {tissue }} / \mathrm{C}_{\text {plasma }}=$ $4.5 \mathrm{~mL} . \mathrm{cm}^{-3}$ (versus $\mathrm{K}_{\mathrm{i}} / \mathrm{k}_{\mathrm{b}}=4.7 \mathrm{~mL} . \mathrm{cm}^{-3}$ ). Second, considering decay-uncorrected data, the differential equation becomes $\mathrm{dC}_{\text {trapped }}(\mathrm{t}) /$ $\mathrm{dt}=\mathrm{K}_{\mathrm{i}} \times \mathrm{C}_{\text {plasma }}(\mathrm{t})-\mathrm{k}_{\mathrm{b}} \times \mathrm{C}_{\text {trapped }}(\mathrm{t})-\lambda \times \mathrm{C}_{\text {trapped }}(\mathrm{t})$, where $\lambda$ is the ${ }^{18} \mathrm{~F}$ physical-decay-rate constant. As a consequence, at peak time of decay-uncorrected- $\mathrm{C}_{\text {trapped }}$ time-activity curve, $\mathrm{C}_{\text {trapped }}\left(\mathrm{t}_{\text {peak }}\right) / \mathrm{C}_{\text {plasma }}\left(\mathrm{t}_{\text {peak }}\right)=$ $\mathrm{K}_{\mathrm{i}} /\left(\mathrm{k}_{\mathrm{b}}+\lambda\right)$. The ratio $\mathrm{K}_{\mathrm{i}} /\left(\mathrm{k}_{\mathrm{b}}+\lambda\right)$ was calculated as $2.1 \mathrm{~mL} . \mathrm{cm}^{-3}$, whereas, at decay-uncorrected- $\mathrm{C}_{\text {trapped }} \mathrm{t}_{\text {peak }}$ of 53 min after injection, the ratio $\mathrm{C}_{\text {tissue }} / \mathrm{C}_{\text {plasma }}$ (that may involve decay correction or not) was found to be $2.2 \mathrm{~mL} \cdot \mathrm{cm}^{-3}$.

We therefore suggest that the $\mathrm{SUV} / \mathrm{C}_{\text {plasma }}$ ratio (or, equivalently, the $\mathrm{C}_{\text {tissue }} / \mathrm{C}_{\text {plasma }}$ ratio) is actually correlated with $V_{T}=$ $\mathrm{K}_{\mathrm{i}} / \mathrm{k}_{\mathrm{b}}$ when assessed within 85-90 min after injection. However, the authors acknowledged that their results were only valid within 50-80 min after injection (1). Furthermore, we suggest that the $\mathrm{SUV} / \mathrm{C}_{\text {plasma }}$ ratio assessed within $50-55 \mathrm{~min}$ after injection should be correlated with $\mathrm{K}_{\mathrm{i}} /\left(\mathrm{k}_{\mathrm{b}}+\lambda\right)$, instead of $\mathrm{K}_{\mathrm{i}} / \mathrm{k}_{\mathrm{b}}$ (1). This alternative ratio reports on what is actually occurring at decayuncorrected- $\mathrm{C}_{\text {trapped }} \mathrm{t}_{\text {peak }}$, that is, an equilibrium between uptake and release plus physical decay. It is worth noting, regarding the part of postinjection time in its measurement uncertainty, a $+13 \%$ increase occurs in the 50-55 min time range, whereas, for comparison, $\mathrm{C}_{\text {tissue }}$ alone, and, hence, $\mathrm{SUV}_{\mathrm{BW}}$, shows a $+3 \%$ increase.

In conclusion, investigating potential clinical biomarkers and relevant simplified metrics is of upmost importance for selecting NSCLC patients who could benefit from immune checkpoint-inhibitor treatment. In ${ }^{18}$ F-BMS-986192 PET imaging, Huisman et al. convincingly showed that $\mathrm{SUV}_{\mathrm{BW}}$, at $60 \mathrm{~min}$ after injection, may be a relevant simplified parameter to quantify tumor uptake for baseline PET studies. We additionally suggest that the ratio $\mathrm{SUV}_{\mathrm{BW}} / \mathrm{C}_{\text {plasma }}$ might be probed as a complementary possible simplified parameter, that is correlated with $\mathrm{K}_{\mathrm{i}} /\left(\mathrm{k}_{\mathrm{b}}+\lambda\right)$ within 50-55 min after injection.

\section{DISCLOSURE}

No potential conflict of interest relevant to this article was reported.

\section{REFERENCES}

1. Huisman M, Niemeijer AL, Windhorst B, et al. Quantification of PD-L1 expression with [18F]BMS-986192 PET/CT in patients with advanced stage non-small-cell lung cancer. $J$ Nucl Med. February 14, 2020 [Epub ahead of print].

2. Innis RB, Cunningham VJ, Delforge J, et al. Consensus nomenclature for in vivo imaging of reversibly binding radioligands. J Cereb Blood Flow Metab. 2007; 27:1533-1539.

3. Laffon E, Calcagni ML, Galli G, et al. Comparison of three-parameter kinetic model analysis to standard Patlak's analysis in ${ }^{18} \mathrm{~F}$-FDG PET imaging of lung cancer patients. EJNMMI Res. 2018;8:24-32.

Eric Laffon*
Roger Marthan
*Service de Médecine Nucléaire, Hôpital Haut-Lévèque
Avenue de Magellan
33604 Pessac, France
E-mail: elaffon@u-bordeaux.fr

Published online May 22, 2020.

DOI: $10.2967 /$ jnumed.120.248484 